\title{
012 発熱・全身倦怠感と共に熱傷㓔痕部に広範囲皮膚病変を生じたサルコイドーシスの1例
}

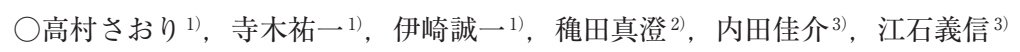

埼玉医科大学総合医療センター 皮膚科1)

埼玉医科大学 解剖学2

東京医科歯科大学 人体病理学 31

62歳女. 22歳時の広範囲熱傷のため皮膚移植の既往あり。C型 肝炎のため, ペグインターフェロン- $\alpha-2 b$ とリバビリン併用療法 を開始した11カ月後より, 両前腕, 体幹に浸潤性紅斑が出現し, 来院した，全身倦㤐感あり。体温38～39度, 体幹, 四肢の熱傷後 の植皮部はびまん性に紅色腫脹し, 一部に紅色結節がみられた。 生検にて真皮内に非乾酪性類上皮細胞肉芽腫あり, 偏光顕微鏡 で観察した結果, 重屈折性を示す異物を多数認めた。ツ反陰性. 胸部CT上, びまん性陰影あり。血清ACE $29.6 \mathrm{U} / \mathrm{L}$, リゾチーム $22.2 \mu \mathrm{g} / \mathrm{ml}$ と上昇. 以上より, 熱傷㓔痕部位に生じた痏痕浸潤型 のサルコイドーシスと診断した。異物組成解析を行った結果, 肉 芽腫内のガラス様異物は, ケイ素およびマグネシウム原子の検出 ピークを示した. さらに, 抗Propionibacterium acnes抗体を用
いた免疫組織化学染色により, 病変を構成する類上皮細胞ならび に巨細胞内に，明瞭な抗原物質が認められた.

\section{3 慢性呼吸不全を呈したサルコイドーシスに左反回神経麻痺を合併した1例}

宮林貴大

新潟市民病院

【症例】78歳 女性【主訴】嗄声, 呼吸困難

【現病歴】X-33年より陳旧性肺結核（治療歴あり）としてA病院 を通院開始した．X-18年に同院でサルコイドーシス(肺, 眼, 皮膚) と組織診断されたが，ステロイド治療は行わず経過観察された。 その後, 徐々に呼吸機能が低下し, X-3年には慢性呼吸不全のた め当院で在宅酸素療法を導入したＸ-2年12月に胃液培養で結 核菌が検出され，9か月間抗結核薬治療を行った，X年1月より嗄 声が出現し，同年4月には呼吸困難を自覚するようになり，当院 神経内科に入院した. 左声带完全麻痺を認めたが, その他神経学 的異常所見はなく, 頭部MRI, 髄液検査, 各種腫瘍マーカー, 感 染症マーカー, 自己抗体は正常だった。胸部CT上, 縦隔リンパ 節の腫大が多発し，両肺の気管支血管束周囲主体の不整形結節の 増悪も認めたことから，サルコイドーシスの増悪による左反回神 経麻痺と判断し, 当科に転科した. 肺結核の既往があり, INH併
用で経口PSL10mg/日で治療を開始したところ, 肺陰影および嗄 声は軽減した。

【考察】サルコイドーシスに反回神経麻痺を合併した報告は少な く, 本症例では低用量ステロイドで臨床症状の軽減が得られたの で報告する。

\section{4 肺サルコイドーシスの経過観察中に発症した多中心性キャッスルマン病の1例}

澤田哲郎

自治医科大学 内科学講座 呼吸器内科学部門

60歳女性. 2005年11月の健診で胸部異常陰影を指摘され，当科 紹介受診した。胸部CT上，縦隔・肺門リンパ節の腫脤と両側上 葉優位にに多発粒状影を認めたため経気管支肺生検を施行し, 肺 サルコイドーシス（II 期）と診断した。陰影は一時自然軽快した が, 低アルブミン血症, ポリクローナルな $\gamma$-グロブリンの上昇, 炎症反応の上昇を認めた。 2012年3月のCTで縦隔，腹腔リンパ節 の腫脹および気管支血管束の肥厚, 多発結節影を認め, その後の 経過観察で陰影が悪化したため, 胸腔鏡下リンパ節・肺生検を施 行した. 生検リンパ節では非乾酪性類上皮細胞肉芽種を認めるの みで形質細胞の浸潤は認めなかったが, 生検肺組織では臟側胸膜 や小葉間隔壁に著明な形質細胞の浸潤やリンパ滤胞を認めた。ま たリンパ球や形質細胞浸潤と線維化のある部分に非乾酪性類上 皮細胞肉芽種を認めた。 以上の病理組織所見と, 血清IL-6 (75.7 $\mathrm{pg} / \mathrm{ml}$ ) の上昇から, サルコイドーシスに多中心性キャッスルマ
ン病が合併したものと判断した。サルコイドーシスの経過観察中 に多中心性キャッスルマン病を発症した症例は稀であり, 両疾患 の関連を含め文献的考察を加えて報告する。 